\title{
MORPHOLOGICAL DIFFERENCES BETWEEN GENETIC LINEAGES OF THE PEREGRINE EARTHWORM APORRECTODEA CALIGINOSA (SAVIGNY, 1826)
}

\author{
Sergei V. Shekhovtsovi ${ }^{1,2, *}$, Sergei A. Ermolov ${ }^{3}$, Tatiana V. Poluboyarova ${ }^{1,2}$ \\ Maria N. Kim-Kashmenskaya ${ }^{1}$, Yevgeniy A. Derzhinsky ${ }^{4}$ and Sergey E. Peltek ${ }^{1}$ \\ ${ }^{1}$ Kurchatov Genomic Center, Institute of Cytology and Genetics SB RAS \\ pr. Lavrientieva 10, 630090, Novosibirsk, Russia \\ E-mails: shekhovtsov@bionet.nsc.ru,* https://orcid.org/0000-0001-5604-5601 \\ poluboyarova@bionet.nsc.ru, https://orcid.org/0000-0002-5652-0553 \\ mashust@gmail.com, https://orcid.org/0000-0003-2891-8000 \\ peltek@bionet.nsc.ru, https://orcid.org/0000-0002-3524-0456 \\ ${ }^{2}$ Institute of Biological Problems of the North FEB RAS, Portovaya 18, 685000, Magadan, Russia \\ ${ }^{3}$ Center for Forest Ecology and Productivity RAS, Profsoyuznaya 84/32 b. 14 \\ 117997, Moscow, Russia; E-mail: ermserg96@gmail.com, https://orcid.org/0000-0002-0634-7641 \\ ${ }^{4}$ Vitebsk State University named after P. M. Masherov \\ Moskovskiy pr. 33, 210038, Vitebsk, Belarus \\ E-mail: dernoctuid@mail.ru, https://orcid.org/0000-0002-1341-585X
}

Aporrectodea caliginosa is a universally distributed and highly abundant peregrine earthworm that is the object of many ecological and ecotoxicological studies. Molecular phylogenetic analysis suggested that $A$. caliginosa consists of three highly diverged genetic lineages. In this study, we investigated morphological diversity within a sample of these three lineages from Belarus. We detected a variety of forms with different degrees of pigmentation and a shift in the clitellum position. The three genetic lineages of $A$. caliginosa demonstrated different propensity to particular morphological variants, including size, colour, and the clitellum position, yet no character could be used to distinguish among the lineages with sufficient accuracy. Thus, our results suggest that identification of the genetic lineage should be recommended for ecological studies involving $A$. caliginosa to account for possible differences between them.

Key words: Aporrectodea caliginosa, earthworms, Lumbricidae, morphological variation, genetic lineages, cryptic diversity.

\section{INTRODUCTION}

Aporrectodea caliginosa (Savigny, 1826) is an endogeic peregrine earthworm. Its original distribution (before the Last Glacial Maximum) was probably in southern Western Europe (HENDrix et al. 2008), from where it spread to all continents except Antarctica (Tiunov et al. 2006, Porco et al. 2013, BART et al. 2018). A. caliginosa is one of the most abundant earthworms found in many natural and particularly agricultural land types in the temperate zone (BoAG et al. 1997, Vsevolodova-Perel 1997, Ivask et al. 2007). 
A. caliginosa is a part of a complex of closely related species, which also includes $A$. trapezoides, $A$. nocturna, and $A$. tuberculata, as well as several other species; the list of the included taxa and their status varies according to different authors (Sims \& Gerard 1985, Pérez-Losada et al. 2009, Fernández et al. 2012). Morphological delimitation among the members of the complex is vague. Molecular analyses recovered $A$. caliginosa either as monophyletic (Pérez-Losada et al. 2009, Fernández et al. 2012) or as polyphyletic (Latif et al. 2020); this issue requires a multigene nuclear dataset to be satisfactorily resolved.

The presence of highly diverged genetic lineages is a well-known phenomenon among earthworms (KIng et al. 2008, Novo et al. 2009, DecaËNs et al. 2013, Marchán et al. 2018, SheKhovtsov et al. 2019). Three genetic lineages of A. caliginosa have been reported (Porco et al. 2013). Although genetic lineages of earthworms are generally considered cryptic, sometimes significant morphological diversity can be found in certain populations (SHEKHOvTsov et al. 2016). It is unclear if certain genetic lineages are truly cryptic or whether there are minor morphological differences among them that have been overlooked (MARChán et al. 2020).

In this study, we investigated the morphological diversity in a sample of the three A. caliginosa genetic lineages from Belarus. We documented various morphological variations that slightly deviate from the typical diagnosis, as well as cases where an individual could be identified as a different species. All specimens were genotyped to verify the morphological identification. Our aim was (1) to identify possible morphological characters that vary between genetic lineages of $A$. caliginosa and (2) to document the extent of morphological variation of the species compared to published diagnoses and the extent of overlap with other species.

\section{MATERIALS AND METHODS}

A. caliginosa individuals were collected in 2019 in Belarus (Fig. 1) and fixed in ethanol. GPS coordinates of the sampled locations are as follows: location $1,55.6419^{\circ} \mathrm{N}, 27.0408^{\circ} \mathrm{E}$ loc. $2,54.9716^{\circ} \mathrm{N}, 26.8700^{\circ} \mathrm{E}$; loc. $3,54.9674^{\circ} \mathrm{N}, 26.8704^{\circ} \mathrm{E}$; loc. $4,54.2142^{\circ} \mathrm{N}, 25.9661^{\circ} \mathrm{E}$; loc 5, $53.2082^{\circ} \mathrm{N}, 26.1010^{\circ} \mathrm{E}$; loc. $6,52.0673^{\circ} \mathrm{N}, 24.9429^{\circ} \mathrm{E}$; loc. $7,54.7315^{\circ} \mathrm{N}, 28.1247^{\circ} \mathrm{E}$; loc. 8 , $55.7302^{\circ} \mathrm{N}, 27.7765^{\circ} \mathrm{E}$; loc. $9,55.9107^{\circ} \mathrm{N}, 27.8889^{\circ} \mathrm{E}$; loc. $10,56.1365^{\circ} \mathrm{N}, 28.1378^{\circ} \mathrm{E}$; loc. 11 , $55.1735^{\circ} \mathrm{N}, 28.8881^{\circ} \mathrm{E}$; loc. $12,55.0518^{\circ} \mathrm{N}, 29.7150^{\circ} \mathrm{E}$; loc. $13,54.4241^{\circ} \mathrm{N}, 29.7967^{\circ} \mathrm{E}$; loc. 14 , $55.1713^{\circ} \mathrm{N}, 30.2665^{\circ} \mathrm{E}$; loc. $15,54.5202^{\circ} \mathrm{N}, 30.2775^{\circ} \mathrm{E}$; loc. $16,54.5175^{\circ} \mathrm{N}, 30.2975^{\circ} \mathrm{E}$.

Preliminary morphological identification was performed according to VsevolodovaPerel (1997). Individuals slightly deviating from the typical diagnosis (Table 1) were taken for the subsequent analysis. We assessed their size (length, width, the length and width of the clitellum), the number of segments, colour, and pigmentation. Welch's test estimated morphological differences between the lineages. Length and width were measured with an 
accuracy of $0.5 \mathrm{~mm}$. For statistical analysis, the position of the clitellum was encoded with an accuracy of $0.25 \times$ segments.

Sequencing of the fragment of the cytochrome c oxidase I gene (COI) was performed with the universal primers LCOm (5'-TACTC-AACAA-ATCAC-AAAGA-TATTG-G-3'; modified from Folmer et al. 1994) and COI-E-(5'-TATAC-TTCTG-GGTGT-CCGAA-GAATC-A-3'; BELY \& WRAY 2004) with the Biomaster HS-Taq PCR Mix (Biolabmix, Russia) as described in Sнекноvтsov et al. (2018a). The amplified fragments were assessed using agarose gel electrophoresis and cleaned by the shrimp alkaline phosphatase/E. coli exonuclease I mix (New England Biolabs, USA). Sanger sequencing was conducted on a 3130xl DNA Analyzer (Applied Biosystems) in SB RAS Genomics Core Facility (ICBFM SB RAS, Novosibirsk, Russia) using both forward and reverse primers. The obtained DNA sequences were manually edited and assembled using Chromas Lite v. 2.0 (www.technelysium.com.au/).

Species/lineage identification was performed using Blast (blast.ncbi.nlm.nih.gov/ Blast.cgi) according to the published sequences of $A$. caliginosa from the studies of PérezLosada et al. (2009), Fernández et al. (2012), Porco et al. (2013), Shekhovtsov et al. (2016, $2018 b$ ). Only unique sequences that were not yet present in GenBank were submitted under accession numbers MW080717-MW080729. Phylogenetic trees were built using the Maximum Parsimony and Maximum Likelihood algorithms with the Mega X program (Kumar et al. 2018). Maximum Parsimony trees were built using the subtree-pruning-regrafting search algorithm. Maximum Likelihood algorithm used the General Time Reversible $(\mathrm{GTR}+\mathrm{I}+\mathrm{G})$ model; 1000 bootstrap replicates were performed for each algorithm.

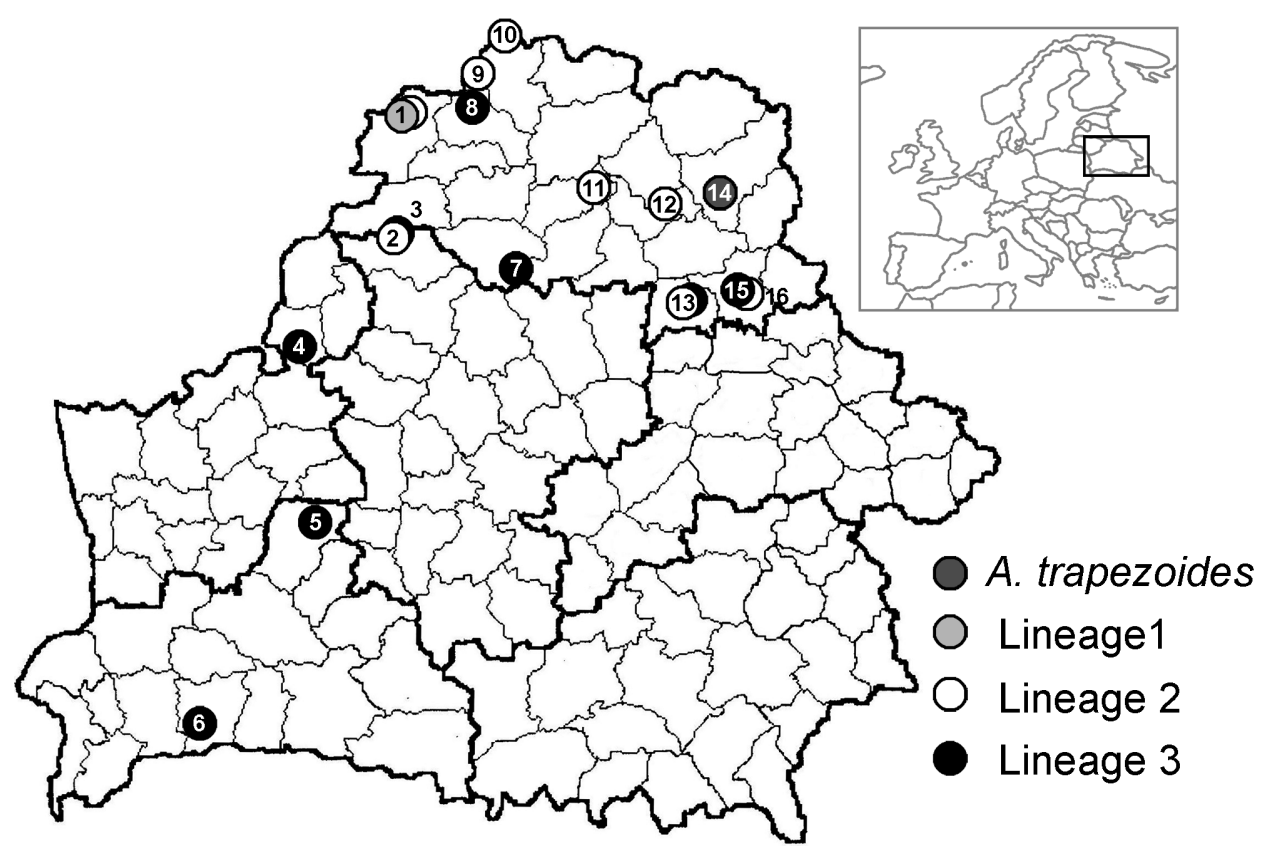

Fig. 1. Sampled sites of A. caliginosa 
Table 1. Morphometry of the A. caliginosa individuals studied here. Nseg = number of segments, $\mathrm{L}=$ body length in $\mathrm{mm}, \mathrm{W}=$ body width in $\mathrm{mm}, \mathrm{CS}=$ clitellum start, $\mathrm{CE}=$ clitellum end, $\mathrm{CL}=$ clitellum length in $\mathrm{mm}, \mathrm{CW}=$ clitellum width in $\mathrm{mm}, \mathrm{TP}=$ tuberculae pubertatis, " = ditto, cli. = clitellum. Haplotype refers to GenBank accessions.

\begin{tabular}{|c|c|c|c|c|c|c|c|c|c|}
\hline Pigmentation & Nseg & $\mathrm{L}$ & W & CS & $\mathrm{CE}$ & $\mathrm{CL}$ & $\mathrm{CW}$ & $\mathrm{TP}$ & haplotype \\
\hline \multicolumn{10}{|c|}{ Lineage 1} \\
\hline absent & 92 & 41 & 2 & 28 & 34.25 & 3 & 3 & & MW080725 \\
\hline " & 121 & 74 & 2.5 & 28.75 & 34.25 & 4 & 3.5 & & “ \\
\hline " & 111 & 55 & 2.5 & 28 & 34 & 3.5 & 3 & & MW080722 \\
\hline " & 108 & 46 & 2 & 28 & 34.25 & 3.5 & 3 & & MW080723 \\
\hline$"$ & 106 & 52 & 2 & 28.5 & 34.25 & 3.5 & 3 & & MW080724 \\
\hline " & 114 & 51 & 2 & 28.75 & 34.25 & 3.5 & 3 & & MW080728 \\
\hline yellowish, post-cli. & 120 & 36 & 2 & 28.75 & 34.25 & 3.5 & 3 & & MW080729 \\
\hline Average & 110.3 & 50.7 & 2.1 & 28.4 & 34.2 & 3.5 & 3.1 & & \\
\hline \multicolumn{10}{|c|}{ Lineage 2} \\
\hline absent & 157 & 62 & 4 & 27 & 35 & 4.5 & 4.5 & & KU358811 \\
\hline " & 158 & 68 & 4 & 27 & 35 & 5 & 5 & & " \\
\hline “" & 150 & 81 & 4 & 27.5 & 35 & 5.5 & 5 & & KF471807 \\
\hline reddish, pre-cli. & 144 & 59 & 3 & 29 & 34.25 & 4 & 3.5 & & KU358811 \\
\hline " & 111 & 47 & 3 & 27.75 & 34.25 & 4 & 4 & & KU358777 \\
\hline$"$ & 177 & 69 & 4 & 27.75 & 34 & 4 & 5 & & KU358820 \\
\hline$"$ & 130 & 78 & 3.5 & 28 & 34 & 5 & 4 & & $"$ \\
\hline “" & 141 & 67 & 3.5 & 28 & 34.25 & 5 & 4 & & " \\
\hline$"$ & 149 & 67 & 3.5 & 28 & 34.25 & 5 & 4 & & $"$ \\
\hline " & 161 & 71 & 4 & 28 & 34.25 & 5 & 4.5 & & MW080718 \\
\hline$"$ & 170 & 61 & 3.5 & 27.75 & 34 & 4 & 4 & & KU358757 \\
\hline$"$ & 155 & 73 & 3.5 & 27.75 & 34 & 5 & 4 & & KU358747 \\
\hline " & 139 & 56 & 3.5 & 28 & 35 & 4 & 4 & & " \\
\hline " & 167 & 71 & 3.5 & 27.5 & 34 & 5.5 & 4 & & \\
\hline reddish, post-cli. & 173 & 83 & 5 & 27 & 34.25 & 5 & 5.5 & & KF471807 \\
\hline brown, pre-cli. & 155 & 61 & 3 & 28 & 34.25 & 4 & 4 & & KU358826 \\
\hline " & 167 & 69 & 3 & 28 & 35 & 4 & 4 & & MW080717 \\
\hline brown, post-cli. & 164 & 73 & 4 & 28 & 34.25 & 5 & 5 & & KF471794 \\
\hline " & 151 & 62 & 4 & 27 & 34 & 4 & 5 & & KF471807 \\
\hline " & 128 & 59 & 5 & 28 & 34 & 4 & 5 & & KF471794 \\
\hline " & 160 & 58 & 4 & 28 & 34.25 & 4 & 4.5 & & $"$ \\
\hline Average & 152.7 & 66.4 & 3.7 & 27.8 & 34.3 & 4.5 & 4.4 & & \\
\hline
\end{tabular}


Table 1 (continued)

\begin{tabular}{|c|c|c|c|c|c|c|c|c|c|}
\hline Pigmentation & Nseg & L & W & CS & $\mathrm{CE}$ & CL & $\mathrm{CW}$ & $\mathrm{TP}$ & haplotype \\
\hline \multicolumn{10}{|c|}{ Lineage 3} \\
\hline absent & 133 & 51 & 2.5 & 28 & 34 & 4 & 3 & & KU358858 \\
\hline “ & 123 & 65 & 3 & 28.75 & 34.25 & 4 & 3.5 & & $"$ \\
\hline " & 130 & 46 & 2.5 & 29 & 35 & 3 & 3 & $32-34$ & $"$ \\
\hline " & 133 & 55 & 3 & 27.75 & 34 & 4 & 4 & & $"$ \\
\hline " & 138 & 54 & 3 & 29 & 34.25 & 4 & 3.5 & & " \\
\hline$"$ & 125 & 55 & 3 & 28 & 34 & 4.5 & 3.5 & & $"$ \\
\hline$"$ & 130 & 50 & 2.5 & 28 & 34 & 4 & 3 & & $"$ \\
\hline " & 130 & 42 & 2 & 29 & 34 & 3 & 3 & & $"$ \\
\hline$"$ & 132 & 38 & 3 & 27 & 37 & 3.5 & 3.5 & $30-32$ & $"$ \\
\hline$"$ & 114 & 69 & 3 & 28.75 & 34 & 4.5 & 4 & as bands & MW080721 \\
\hline$"$ & 126 & 66 & 3 & 28.75 & 34.25 & 5 & 4 & & KU358856 \\
\hline$"$ & 131 & 71 & 3 & 28.75 & 34.25 & 4.5 & 4 & & KU358841 \\
\hline$"$ & 158 & 58 & 3 & 27.5 & 34.5 & 4 & 3.5 & & KU358862 \\
\hline$"$ & 156 & 77 & 3 & 28.5 & 34.5 & 5 & 4 & as bands & MW080727 \\
\hline$"$ & 134 & 39 & 2.5 & 29 & 34 & 3 & 3 & & MW080726 \\
\hline reddish orange, pre-cli. & 163 & 53 & 3 & 28.75 & 34.25 & 3.5 & 4 & & KU358862 \\
\hline$"$ & 147 & 46 & 3 & 28.75 & 34 & 4 & 4 & & $"$ \\
\hline$"$ & 147 & 47 & 2.5 & 28.75 & 34 & 4 & 3 & & KU358858 \\
\hline “ & 150 & 49 & 3 & 28.75 & 34 & 4 & 4 & & KU358873 \\
\hline yellowish, pre-cli. & 131 & 71 & 3.5 & 28.5 & 34.5 & 4 & 4 & & KU358858 \\
\hline “ & 137 & 52 & 3 & 28.75 & 34.25 & 4 & 3.5 & & $"$ \\
\hline$"$ & 139 & 52 & 3 & 28.5 & 35 & 4.5 & 4 & & KU358862 \\
\hline$"$ & 118 & 51 & 3 & 28 & 34.25 & 4 & 4 & & $"$ \\
\hline “ & 166 & 56 & 3 & 28.5 & 34.5 & 4 & 4 & & $"$ \\
\hline “ & 144 & 55 & 3 & 28.5 & 34.5 & 4.5 & 4 & & $"$ \\
\hline “ & 143 & 47 & 3 & 28.75 & 34 & 3.5 & 4 & & $"$ \\
\hline$"$ & 136 & 46 & 3 & 28.75 & 34 & 3 & 4 & & " \\
\hline yellowish, post-cli. & 131 & 78 & 3 & 28.5 & 34.5 & 5 & 4 & & MW080719 \\
\hline greyish brown, post-cli. & 142 & 68 & 3.5 & 28 & 34.25 & 4 & 4 & & MW080720 \\
\hline brown, post-cli. & 124 & 46 & 2 & 28 & 35 & 3.5 & 3 & & KU358862 \\
\hline Average & 137.0 & 55.1 & 2.9 & 28.5 & 34.4 & 4.0 & 3.7 & & \\
\hline \multicolumn{10}{|c|}{ A. trapezoides } \\
\hline brown, post-cli. & 165 & 80 & 4 & 27 & 35 & 5.5 & 5 & & КT073944 \\
\hline
\end{tabular}




\section{RESULTS}

We studied a total of 251 adult $A$. caliginosa individuals from Belarus. In this sample, we identified a set of 59 individuals (Table 1) with deviations from the diagnosis of Vsevolodova-Perel (1997). The final sample included earthworms with different degree of pigmentation: reddish-brown, yellowish-brown or light red, as well as different variants of the position of the clitellum. The position and form of the tuberculae pubertatis were typical for $A$. caliginosa, except for four individuals.

DNA sequencing demonstrated that the studied sample contained all three known lineages of $A$. caliginosa. The extent of genetic differences between the lineages was similar to that found in previous studies (Fig. 2). Differences in most parameters among the lineages turned out to be statistically

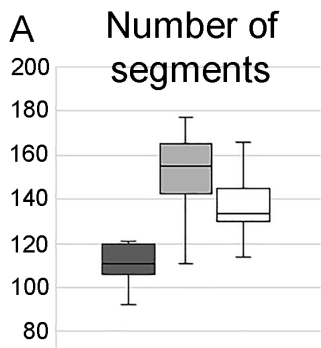

L1 L2 L3
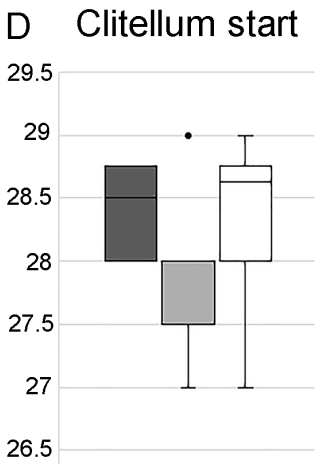

L1 L2 L3

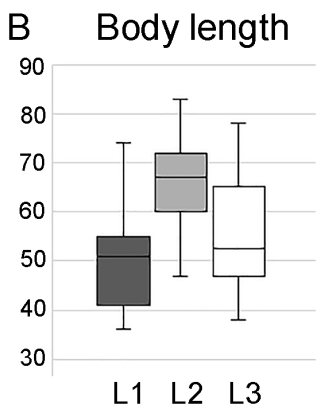

E Clitellum length

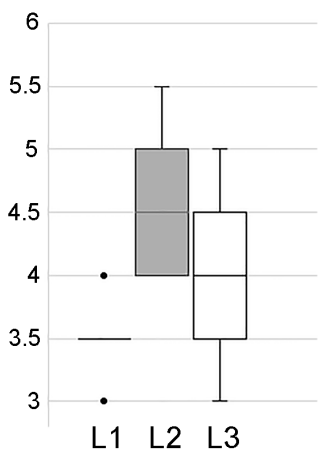

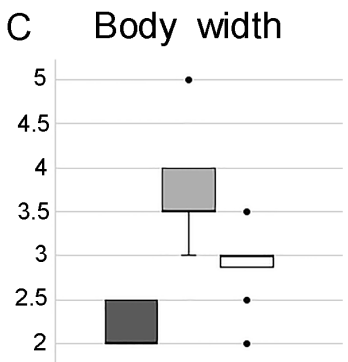

L1 L2 L3

\section{F Clitellum width}

6
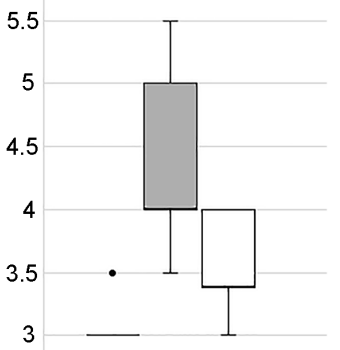

L1 L2 L3

Fig. 2. Box with whiskers plots for the data in Table 1: A, number of segments; B, body length (mm); C, body width ( $\mathrm{mm})$, D, clitellum start; E, clitellum length ( $\mathrm{mm})$; F, clitellum width $(\mathrm{mm})$. Dark grey, lineage 1; light grey, lineage 2; white, lineage 3 . Boundaries of the box stand for the 25th and the 75th percentiles; line within the box denotes the median; if the median coincides with box border, it is shown as a bold line; whiskers represent the 1.5 interquartile ranges; dots stand for outliers. 
Table 2. Comparison among A. caliginosa lineages using Welch's t-test; L1, L2, L3 refer to the corresponding genetic lineages.

\begin{tabular}{lccc}
\hline & L1 vs. L2 & L1 vs. L3 & L2 vs. L3 \\
\hline Body length & $<0.05$ & - & $<0.001$ \\
Body width & $<0.001$ & $<0.001$ & $<0.001$ \\
No. of segments & $<0.001$ & $<0.001$ & $<0.001$ \\
Clitellum start & $<0.01$ & - & $<0.001$ \\
Clitellum end & - & - & - \\
Clitellum length & $<0.001$ & $<0.01$ & $<0.01$ \\
Clitellum width & $<0.001$ & $<0.001$ & $<0.001$ \\
\hline
\end{tabular}

significant: body length and width, clitellum length and width, the number of segments and the anterior position of the clitellum (Table 2). Lineages 1 and 3 were closer in these parameters to each other than to lineage 2 . The only parameter that demonstrated no differences among the lineages was the posterior position of the clitellum.

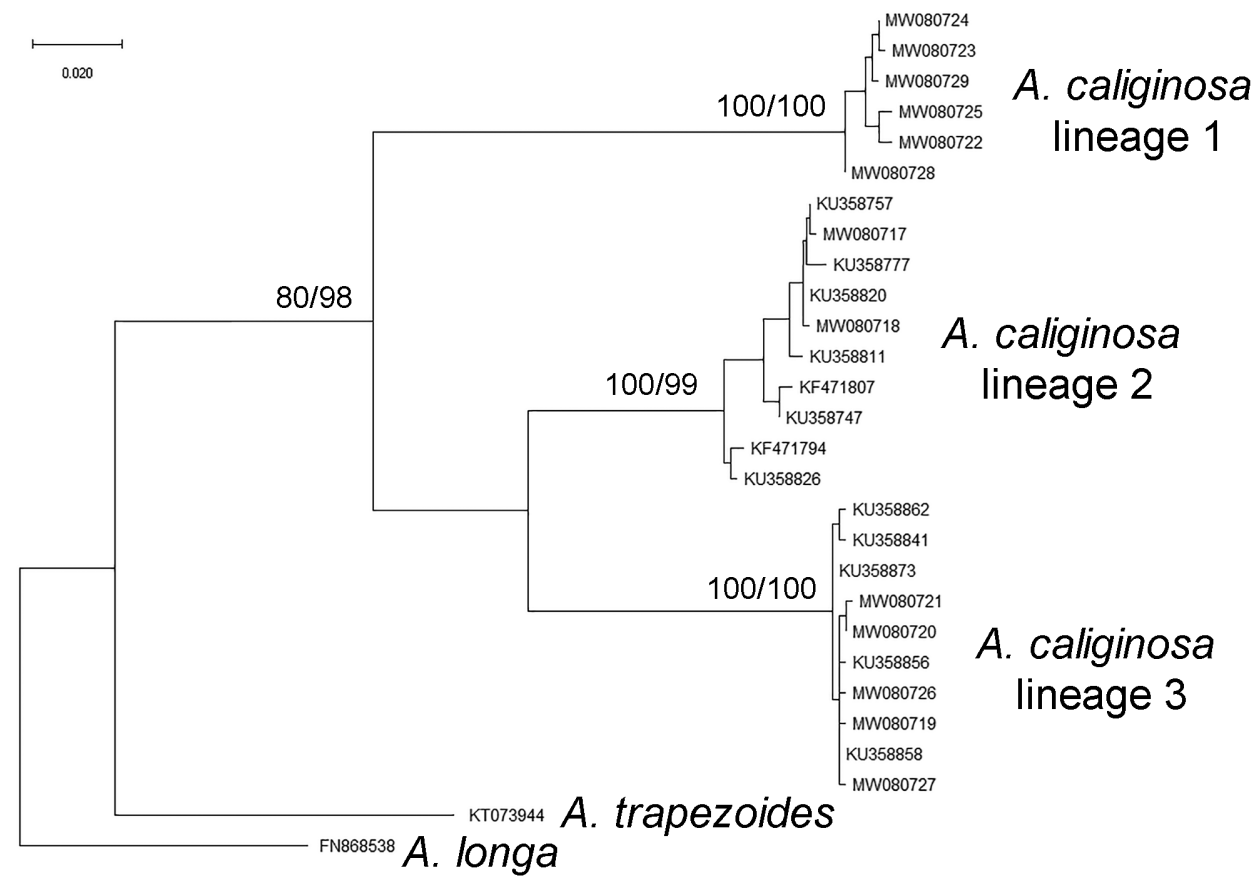

Fig. 3. Maximum likelihood phylogenetic tree of the obtained sequences. Numbers near the branches denote Maximum Parsimony/Maximum Likelihood bootstrap support 


\section{DISCUSSION}

Morphological variation in A. caliginosa

Earthworms are generally identified using identification keys and diagnoses. However, published diagnoses tend to set strict limits and omit outlier variants that may account for a significant portion of the population. Moreover, the descriptions of $A$. caliginosa vary in different sources. In the former Soviet Union, A. caliginosa is usually identified using Vsevolodova-Perel's (1997) key, which specifies the position of the clitellum on the segments 27 34/35. Other sources give a broader diagnosis, e.g. 25/26/(29) - 34/35 (Csuzdi \& Zicsi 2003, Mezhzherin et al. 2018). In the sample from Belarus, clitellum started on the segments $27 / 28 / 29$ and ended on 33 or 34 . Earlier we reported a population of $A$. caliginosa from Russia with the clitellum ranging from $26^{\text {th }}$ to the 32nd segments (SheKHovtsov et al. 2016). Thus, the clitellum position in A. caliginosa may range from $25 / 26 / 27 / 28 / 29$ to $32 / 33 / 34 / 35$. This variation may partly be explained by the fact that the clitellum's extent varies depending on the reproductive cycle: during the maximum extent of clitellum it encroaches on the neighbouring segments (our observations).

The tuberculae pubertatis turned out to be a more constant character. The shift in their position was observed in only two specimens, from the segments 31-33 to 30-32 and 32-34, respectively. Form of tuberculae pubertatis is an important character that distinguishes $A$. caliginosa from the closely related $A$. trapezoides (alongside with pigmentation). The majority of the studied individuals had tuberculae pubertatis as two more or less pronounced protuberances, typical for A. caliginosa. However, in two individuals, those formed pads, characteristic for $A$. trapezoides.

Body colour is an important character in the A. caliginosa complex: $A$. caliginosa differs from the closely related $A$. trapezoides by the absence of pigmentation. Although most of the studied individuals were nonpigmented, some had reddish, brownish, or yellowish pigmentation, thus resembling A. trapezoides or A. nocturna. Similar variation in colouration was reported in Ukraine (MezhzHerin et al. 2018). DNA analysis identified most of the specimens studied by us as A. caliginosa. However, an individual from one location turned out to be the real $A$. trapezoides, representing the first reported case of this species for Belarus (MaKsimova \& GuRINA 2014).

As seen from the data above, morphological variation in $A$. caliginosa is significant, and based on the external characters some of the pigmented individuals could be identified as A. trapezoides or A. nocturna, depending on the key used. A. trapezoides differs from $A$. caliginosa by having brown pigmentation and by the form of tuberculae pubertatis (pads instead of protuberances; Vsevolodova-Perel 1997). A. nocturna is a large endogeic earthworm 
differing from $A$. caliginosa by its size and dark brown pigmentation (Sims \& Gerard 1985); however, size can also vary widely and some individuals in our sample were close to the lower size limit specified for A. nocturna. Moreover, the individual with the tuberculae pubertatis located on the segments 30-32 was morphologically closer to Eisenia uralensis Malevič, 1950, an endemic species from the Urals (Vsevolodova-Perel 1997). Thus, we could conclude that the accuracy of identification and the resulting species count can be heavily influenced by intraspecific variation, and DNA analysis is required to clarify contentious cases.

\section{Differences between genetic lineages}

Different lineages demonstrated distinct tendencies towards particular character states when comparing the sample of individuals with slightly aberrant phenotypes. Lineage 1 was significantly smaller than lineages 2 and 3 , with fewer segments and smaller clitellum (Table 1, Fig. 2); only one pigmented individual was detected for this lineage. Lineage 2 was the biggest of all three and also tended towards earlier start of the clitellum, by about $3 / 4$ of a segment compared to lineage 3 .

We should note that the sample was collected from multiple locations, and such characteristics as size and colour may be affected by environmental factors (Piearce et al. 2002; García \& Fragoso 2003), so controlled laboratory experiments are needed to verify these morphological differences. On the other hand, genetic differences between the lineages might make them occupy somewhat different environments.

A. caliginosa is recognized as one of the most important and widespread earthworms associated with agricultural lands (BoAg et al. 1997, VsEvolodoVA-Perel 1997, IVASK et al. 2007) and thus as an important model organism in ecological and applied studies (BART et al. 2018). However, as seen from our results, different genetic lineages demonstrate significant differences and thus may behave differently in such studies. It thus seems that identification of the genetic lineage used should be recommended for ecological studies involving A. caliginosa to account for possible biases when comparing different studies.

\section{CONCLUSIONS}

In this study, we investigated morphological diversity within A. caliginosa and detected a variety of forms with different degrees of pigmentation and shifts in the position of the clitellum; some of the studied individuals could be identified as representatives of other species based on the external morphology alone. The three genetic lineages of A. caliginosa demonstrated 
a different propensity to particular morphological variants, yet no character could be used to distinguish among the lineages with sufficient accuracy. This indicates that these lineages may have different ecological characteristics that should be taken into account in ecological and ecotoxicological studies.

Acknowledgements - This study was supported by grants of the Russian Foundation for Basic Research № 19-54-04006_Bel_mol_a and 19-04-00661, the Belarusian Republican Foundation for Fundamental Research № 20191920, the Budget Project no. 0259-2021-0010, and by the Kurchatov Genomic Center of the Institute of Cytology and Genetics of Siberian Branch of the Russian Academy of Sciences (Novosibirsk, Russia) according to the agreement with the Ministry of Education and Science RF, No. 075-15-2019-1662. Sanger sequencing was conducted on 3130xl DNA Analyzer (Applied Biosystems) in SB RAS Genomics Core Facility (ICBFM SB RAS, Novosibirsk, Russia). We thank two anonymous reviewers for improving the manuscript.

\section{REFERENCES}

Bart, S., Amossé, J., Lowe, C. N., Mougin, C., Péry, A. R. R. \& Pelosi, C. (2018): Aporrectodea caliginosa, a relevant earthworm species for a posteriori pesticide risk assessment: current knowledge and recommendations for culture and experimental design. - Environmental Science and Pollution Research 25(34): 33867-33881. https://doi. org/10.1007/s11356-018-2579-9

BeLY, A. E. \& WrAY, G. A. (2004): Molecular phylogeny of naidid worms (Annelida: Clitellata) based on cytochrome oxidase I. - Molecular Phylogenetics and Evolution 30(1): 50-63. https://doi.org/10.1016/S1055-7903(03)00180-5

Boag, B., Palmer, L. F., Neilson, R., Legg, R. \& Chambers, S. J. (1997): Distribution, prevalence and intensity of earthworm populations in arable land and grassland in Scotland. - Annals of Applied Biology 130(1): 153-165. https://doi.org/10.1111/j.1744-7348.1997. tb05791.x

Csuzdi, C. \& Zicsi, A. (2003): Earthworms of Hungary (Annelida: Oligochaeta, Lumbricidae). Hungarian Natural History Museum, Budapest, 278 pp.

Decaëns, T., Porco, D., Rougerie, R., Brown, G. G. \& James, S. W. (2013): Potential of DNA barcoding for earthworm research in taxonomy and ecology. - Applied Soil Ecology 65: 35-42. https://doi.org/10.1016/j.apsoil.2013.01.001

Fernández, R., Almodóvar, A., Novo, M., Simancas, B. \& Díaz Cosín, D. J. (2012): Adding complexity to the complex: New insights into the phylogeny, diversification and origin of parthenogenesis in the Aporrectodea caliginosa species complex (Oligochaeta, Lumbricidae). - Molecular Phylogenetics and Evolution 64(2): 368-379. https://doi. org/10.1016/j.ympev.2012.04.011

Folmer, O., Hoen, W. R., Black, M. B. \& Vrijenhoek, R. C. (1994): Conserved primers for PCR amplification of mitochondrial DNA from different invertebrate phyla. - Molecular Marine Biology and Biotechnology 3: 294-299.

García, J. A. \& Fragoso, C. (2003): Influence of different food substrates on growth and reproduction of two tropical earthworm species (Pontoscolex corethrurus and Amynthas corticis). - Pedobiologia 47(5-6): 754-763. https://doi.org/10.1078/0031-4056-00255 
Hendrix, P. F., Callaham, M. A., Drake, J. M., Huang, C.-Y., James, S. W., Snyder, B. A. \& ZhANG, W. (2008): Pandora's box contained bait: the global problem of introduced earthworms. - Annual Review of Ecology, Evolution, and Systematics 39(1): 593-613. https://doi.org/10.1146/annurev.ecolsys.39.110707.173426

Ivask, M., KuU, A. \& Sizov, E. (2007): Abundance of earthworm species in Estonian arable soils. - European Journal of Soil Biology 43: S39-S42. https://doi.org/10.1016/j.ejsobi.2007.08.006

King, R. A., Tibble, A. L. \& Symondson, W. O. C. (2008): Opening a can of worms: Unprecedented sympatric cryptic diversity within British lumbricid earthworms. - Molecular Ecology 17(21): 4684-4698. https://doi.org/10.1111/j.1365-294X.2008.03931.x

Kumar, S., Stecher, G., Li, M., Knyaz, C. \& Tamura, K. (2018): MEGA X: molecular evolutionary genetics analysis across computing platforms. - Molecular Biology and Evolution 35(6): 1547-1549. https://doi.org/10.1093/molbev/msy096

Latif, R., Malek, M., Aminjan, A. R., Pasantes, J. J., Briones, M. J. I. \& Csuzdi, C. (2020): Integrative taxonomy of some Iranian peregrine earthworm species using morphology and barcoding (Annelida: Megadrili). - Zootaxa 4877(1): zootaxa-4877. https:// doi.org/10.11646/zootaxa.4877.1.7

Maksimova, S. L. \& Gurina, N. V. (2014): Earthworm (Lumbricidae) of the fauna of Belarus: reference guide. - Belarusskaya navuka, Minsk, $56 \mathrm{pp}$.

Marchán, D. F., Cosín, D. J. D. \& Novo, M. (2018): Why are we blind to cryptic species? Lessons from the eyeless. - European Journal of Soil Biology 86: 49-51. https://doi. org/10.1016/j.ejsobi.2018.03.004

Marchán, D. F., Fernández, R., Domínguez, J., Díaz Cosín, D. J. \& Novo, M. (2020): Genome-informed integrative taxonomic description of three cryptic species in the earthworm genus Carpetania (Oligochaeta, Hormogastridae). - Systematics and Biodiversity 18(3): 203-215. https://doi.org/10.1080/14772000.2020.1730474

Mezhzherin, S. V., Garbar, A. V., Vlasenko, R. P., Onishchuk, I. P., Kotsyuba, I. Y. \& Zhalai, E. I. (2018): The evolutionary paradox of parthenogenetic earthworms. - Naukova Dumka, Kiev, 231 pp. [In Russian]

Novo, M., Almodóvar, A. \& Díaz-Cosín, D. J. (2009): High genetic divergence of hormogastrid earthworms (Annelida, Oligochaeta) in the central Iberian Peninsula: evolutionary and demographic implications. - Zoologica Scripta 38(5): 537-552. https:// doi.org/10.1111/j.1463-6409.2009.00389.x

Pérez-Losada, M., Ricoy, M., Marshall, J. C. \& Domínguez, J. (2009): Phylogenetic assessment of the earthworm Aporrectodea caliginosa species complex (Oligochaeta: Lumbricidae) based on mitochondrial and nuclear DNA sequences. - Molecular Phylogenetics and Evolution 52(2): 293-302. https://doi.org/10.1016/j.ympev.2009.04.003

Piefrce, T. (2002): Yellow earthworms: distinctive pigmentation associated with arsenicand copper-tolerance in Lumbricus rubellus. - Soil Biology and Biochemistry 34(12): 1833-1838. https://doi.org/10.1016/S0038-0717(02)00176-1

Porco, D., Decaëns, T., Deharveng, L., James, S. W., Skarzyński, D., Erséus, C., Butt, K. R., Richard, B. \& Hebert, P. D. N. (2013): Biological invasions in soil: DNA barcoding as a monitoring tool in a multiple taxa survey targeting European earthworms and springtails in North America. - Biological Invasions 15(4): 899-910. https://doi. org/10.1007/s10530-012-0338-2

Shekhovtsov, S. V., Golovanova, E. V. \& Peltek, S. E. (2016): Different dispersal histories of lineages of the earthworm Aporrectodea caliginosa (Lumbricidae, Annelida) in the Palearctic. - Biological Invasions 18: 751-761. https://doi.org/10.1007/s10530-015-1045-6 
Shekhovtsov, S. V., Berman, D. I., Bulakhova, N. A., Makarova, O. L. \& Peltek, S. E. (2018a): Phylogeography of earthworms from high latitudes of Eurasia. - Acta Zoologica Academiae Scientiarum Hungaricae 64(4): 369-382. https://doi.org/10.17109/ AZH.64.4.369.2018

Shekhovtsov, S. V., Sundukov, Y. N., Blakemore, R. J., Gongalsky, K. B. \& Peltek, S. E. (2018b): Identifying earthworms (Oligochaeta, Megadrili) of the southern Kuril islands using DNA barcodes. - Animal Biodiversity and Conservation 41(1): 9-17. https:// doi.org/10.32800/abc.2018.41.0009

Shekhovtsov, S. V., Ershov, N. I., Vasiliev, G. V. \& Peltek, S. E. (2019): Transcriptomic analysis confirms differences among nuclear genomes of cryptic earthworm lineages living in sympatry. - BMC Evolutionary Biology 19: 50. https://doi.org/10.1186/s12862019-1370-y

Sims, R. W. \& GERARD, B. M. (1985): Earthworms: keys and notes for the identification and study of the species. Vol. 31. - Brill Archive, $157 \mathrm{pp}$.

Tiunov, A. V., Hale, C. M., Holdsworth, A. R. \& Vsevolodova-Perel, T. S. (2006): Invasion patterns of Lumbricidae into the previously earthworm-free areas of northeastern Europe and the western Great Lakes region of North America. Pp. 23-34. In: Hendrix, P. F. (ed.): Biological invasions below ground: earthworms as invasive species. - Springer Netherlands, Dordrecht. https://doi.org/10.1007/978-1-4020-5429-7_4

Vsevolodova-Perel, T. S. (1997): The earthworms of the fauna of Russia. - Nauka, Moscow, 103 pp. [in Russian]

Received November 11, 2020, accepted February 7, 2021, published August 16, 2021 